\title{
'A JUSTIFIABLE SELF-PREFERENCE'? JUDICIAL DEFERENCE IN POST-9/11 CONTROL ORDER AND ENEMY COMBATANT DETENTION JURISPRUDENCE
}

Nino Guruli

\begin{abstract}
This paper is an examination of the level of judicial deference, or scrutiny, of executive decision making in the war on terror in the United States and the United Kingdom. What kind of judicial process is available before those the executive deems a threat, are deprived of their civil rights? And how is the threat they pose determined within each jurisdiction?
\end{abstract}

\section{Keywords}

Judicial review, deference, national security, Human Rights Act, Bill of Rights, due process

\section{Introduction}

Justice Oliver Wendell Holmes of the United States Supreme Court wrote:

[A]t the bottom of all private relations, however tempered by sympathy and all the social feelings, is a justifiable self-preference. If a man is on a plank in the deep sea which will only float one, and a stranger lays hold of it, he will thrust him off if he can. When the state finds itself in a similar position, it does the same thing. ${ }^{1}$

Here is an unsentimental description of why and how the state justifiesindependent of legal sanction, philosophical coherence, or historical importance of sovereignty-the treatment of a threat with unboundedness unfathomable by any measure of universal human dignity. Does and should the state treat 'others' with a similar impulse when it is threatened? Or is such a basic instinct trumped by a legal process meant to facilitate a clear and legal accounting?

This paper is an examination of the level of judicial deference, or scrutiny, of executive decision making in the war on terror in the United States and the

\footnotetext{
PhD Candidate, University of Cambridge.

1 Oliver Wendell Holmes, The Common Law (1881) 44.
}

Copyright $\odot$ the Author(s).

This work is licensed under a Creative Commons Attribution-NonCommercial-NoDerivs 3.0 License. 
United Kingdom. What kind of judicial process is available before those the executive deems a threat, are deprived of their civil rights? And how is the threat they pose determined within each jurisdiction? The powers under consideration are those which threaten individual liberty and rights through a preventative regime constructed to address the threat from international terrorism after the attacks of 11 September 2001. It is the detention/control order/TPIM regime in the United Kingdom and Guantanamo detention in the United States. At some point, a justification is offered as to why 'they' should not, cannot, be subject to the regular police powers of the state. The justification usually does, and ought, to provide a definition of who 'they' are and why the harm they pose is categorically different, why the regular balance struck between liberty, security, and certainty is no longer adequate. But what does the comparative look tell us about the strength of the judicial process meant to justify this self-preference?

The difference in the level of judicial review is significantly connected to the framing of the limitation on executive authority, whether the emphasis is on institutional competence or individual rights. One, the United States, connects the legislative act empowering this special legal regime to an enumerated constitutional power: a declaration of war or authorization for the use of military force. The Constitution requires a legislative determination moving the state into a recognizable legal relationship with another state, or entity, and their members. ${ }^{2}$ The justification for the alternative legal order is premised on a state of affairs writ large: it's us against them. And even more importantly, that state of affairs has a set of rules, international laws governing armed conflict and domestic rules which recognize legal powers of the executive premised on the extraordinary needs during a state of armed conflict. The armed conflict approach is preoccupied with categories. The detention regime operating at Guantanamo Bay, and the litigation it has spawned, is tied to determining the scope and limits of the executive's authority to detain the enemy in an armed conflict. This means the questions of due process, the nature of individual rights, and the role of the judiciary are defined through a very specific lens. The institutional powers

2 Constitution of the United States of America, Art I, s 8 ('declare war, grant letters of marque and reprisal, and make rules concerning captures on land and water; to raise and support armies, ...[and to] make rules for the government and regulation of the land and naval forces.') See also Hamdi v Rumsfeld, 542 US 507, 519 (2004) (Hamdi) (O'Connor J): 'In light of these principles, it is of no moment that the AUMF does not use specific language of detention. Because detention to prevent a combatant's return to the battlefield is a fundamental incident of waging war, in permitting the use of "necessary and appropriate force," Congress has clearly and unmistakeably authorized detention in the narrow circumstances considered here.' 
occupy an altered prominence when the state power being exercised is one of war.

The other system, the United Kingdom, offers a more flexible justification, prudentially tailored. It is built on statutory authorization, like any other, permitting wide discretion to the executive but subject to regular judicial review. And so, the limit on the authorized power of the executive comes directly from the rights provided for in the European Convention of Human Rights ${ }^{3}$ $(E C H R)$ and not from broader constitutionally enumerated or implied limits on institutional powers. Questions of institutional competencies do arise but they do so in the context of the particular circumstances of the case. And according to the proportionality review which accompanies ECHR rights, the courts are directly engaged in weighing the government interests against the imposition on individual rights for each person, according to their circumstances. While both systems display a quality of diminished judicial confidence in challenging the executive determinations of necessity and risk, the difference in the main source of judicial oversight does impact the quality and strength of judicial review and process. 4

The level of judicial engagement has meant significant differences in the substantive analyses. The separation of powers concerns that permeate the DC Circuit's handling of detention review is preoccupied with safeguarding that sphere of executive discretion which may be necessary or reasonable for successful military operations. And the DC Circuit has been able to do this, without deep doctrinal conflict or judicial assertion of authority to engage with the balancing at stake by avoiding the balancing all together. There has been no articulation of either the exact state interests at stake in any given case or the severity of the deprivation for the individual. The central question is whether there is any possible interpretation that would lead the relevant executive officer, a soldier in the field or an intelligence officer, to believe this person is a 'part of' al-Qaeda, the Taliban, or an associated force. If so, then the executive is operating within his domain and any further judicial involvement is an unacceptable intrusion. If rights are a peripheral, if all together an absent, element in the

\footnotetext{
34 November 1950, 213 UNTS 221.

${ }^{4}$ The judicial deference which informs the handling of policy and risk determinations of the state is the result of traditional designation of national security as $\mathrm{s}$ distinct subject matter, worthy of some deference, which is often a companion of, but not doctrinally, exclusively, or constitutionally tied to war. The legitimacy of such deference is premised on relative institutional competencies which acknowledges the superior expertise and knowledge of the executive officers to assess risk.
} 
US analysis, they are much more central in the UKs. The reason for that is the prominence of the ECHR and the Human Rights Act 1998 (HRA) in the design of the statutory authorization as well as in the judicial interpretation. No doubt, the UK Parliament included mechanisms of judicial oversight beyond what it may have done absent the requirements of the ECHR. But the courts also interpreted a wider scope for judicial review than the statutory language intended. ${ }^{5}$ As a result, the UK High Court and the Court of Appeal have been engaged in sophisticated substantive analysis of the competing interests at stake and how much the imposing preventative measures are justified by the circumstances in each case.

\section{Justifying Self-preference and Judicial Review: Institutional Powers or Individual Rights}

If we could say that the US Constitution was, solely, exclusively, and reductively, a compact between citizens of the state and their government, the answer of where threats from non-members fit may be fairly straightforward, and not too dissimilar to the sentiment expressed by Justice Holmes that the Constitution creates a bond between the people and their government which 'justifies' the preferential privileges it provides. If you are a citizen you have full rights, if not, then your rights are contingent and limited. But more than a mere contract based on reciprocity, the Constitution is also the very source of legitimate exercises of power and so it regulates the governments conduct depending on the kind of state power at issue. ${ }^{6}$ In his concurrence in Verdugo-Urquidez, Justice Kennedy implied just such a distinction in principle:

We should note, however, that the absence of this relation does not depend on the idea that only a limited class of persons ratified the instrument that formed our Government. Though it must be beyond dispute that persons outside the United States did not and could not assent to the Constitution, that is quite irrelevant to any

\footnotetext{
5 A Tomkins, 'National security and the role of the court: a changed landscape?' (2010) 126 LQR 543, 555: 'Even if s 3(10) does not provide on its face that older, lighter-touch standards should no longer apply, the interpretative obligation placed on courts by s 3 of the Human Rights Act should be borne in mind'.

6 See C Keitner, 'Rights Beyond Borders' (2011) 36 Yale JIL 55, 57 (discussing three approaches to rights: country or territory based systems, compact or citizenship based systems, and conscience or government structure and authority reasons).
} 
construction of the powers conferred or the limitations imposed by it. $^{7}$

In other words, the Constitutional protections are not solely about the person's ties or rights, it is also, and often, about the structural scope of or limits on uses of any particular branches power. ${ }^{8}$ And this has been especially true of the Guantanamo jurisprudence. Structure, not rights, is at the heart of the struggle to find a proper balance. The general ordering of institutional competencies which frames substantive analysis of any given exercise of state power varies depending on which source of national power the state hopes to use. If it is the criminal justice power, then the alienage of the defendant or the seriousness of the crime will have no impact on the application of Constitutional criminal justice rights. ${ }^{9}$ Immigration powers certainly provide a lesser set of rights and procedural protections, but this power has not been as heavily relied upon, at least since the immediate reaction after $9 / 11 .^{10}$ But the United States government has

7 United States $v$ Verdugo-Urquidez, 494 US 259, 275-76 (1990) (Kennedy J, concurring) (VerdugoUrquidez): 'The absence of local judges or magistrates available to issue warrant, the differing and perhaps unascertainable conceptions of reasonableness and privacy that prevail abroad, and the need to cooperate with foreign officials all indicate that the Fourth Amendment's warrant requirement should not apply in Mexico as it does in this country'.

8 Whether Justice Kennedy meant to suggest a complete separation between the structural limits on state power and those imposed by the Bill of Rights by way of a grant of rights to the people, this has to some extent been the result.

9 Constitutional criminal procedure does not change based on who the defendant is and how the state classifies him. When the commission of the crime, or the investigation, is carried out extraterritorially, the application of constitutional limits on investigative powers is tailored to account for the practical realities of the reach of state power. For an evolution of legal reasoning addressing the reach of the Bill of Rights in cases of extraterritorial commission, apprehension, and investigation of crime see: Verdugo-Urquidez, above n 7; Ross v McIntyre, 140 US 453 (1891); Reid v Covert, 354 US 1, 6 (1957): 'The United States is entirely a creature of the Constitution. Its power and authority have no other source. [...] When the Government reaches out to punish a citizen who is abroad, the shield which the Bill of Rights and other parts of the Constitution provide to protect his life and liberty should not be stripped away just because he happens to be in another land'. See generally J A Cabranes, 'Our Imperial Criminal Procedure: Problems in the Extraterritorial Application of US Constitutional Law' (2009) 118 Yale LJ 1660; B W Horn, 'The Extraterritorial Application of the Fifth Amendment Protection against Coerced Self-Incrimination' (1992) 2 Duke JCIL 367.

${ }^{10}$ For more examples of the use of immigration powers in the name of national security see: Glavan v Press, 347 US 522 (1954), concerning a Mexican immigrant who, between 1944 and 1946, had become a member of the local branch of the Communist Party, an organization that the US government deemed to be hostile to the interests and security of the nation and grounds for deportation according to the Internal Security Act of 1950. The Court held due process 
predominantly relied on executive powers in time of war to justify preventative detention. The prominent role played by structural analysis places the emphasis on institutional domains. The Article II commander in chief clause is the doctrinal rooting for claims of flexible and broad executive discretion. Article I section 8 'to declare war' and 'make rules concerning captures on land and water' clauses place the legislative branch as the ultimate authority. ${ }^{11}$ And finally, the principle of separation of powers and the judicial role in safeguarding against executive overreaching has meant a constant call for some judicial involvement. ${ }^{12}$

In the United Kingdom, the main limit on the Secretary of State's authority to address the risk from those engaged in 'terrorism related activity' is one from ECHR rights of those who would be affected. ${ }^{13}$ The judicial role envisioned in the Anti-terrorism, Crime and Security Act 2001, the Prevention of Terrorism Act 2005, and the Terrorism Prevention and Investigation Measures Act 2011 is meant to satisfy the UK's obligations under the ECHR and the HRA. The statutory

was satisfied without judicial determination of threat because Congress has made an explicit determination of the significance of membership to national security. D Cole, 'In Aid of Removal: Due Process Limits on Immigration Detention' (2002) 51 Emory LJ 1003; S C Blum, “Use it and Lose it": An Exploration of Unused Counterterrorism Laws and Implication for Future Counterterrorism Policies' (2012) 16 Lewis \& Clark LR 677 (a discussion of the US government powers under the Uniting and Strengthening America by Providing Appropriate Tools Required to Intercept and Obstruct Terrorism Act of 2001 (USA PATRIOT Act) to detain aliens indefinitely, which it has never used).

${ }^{11}$ Hamdi, above n 2, 519: '[i] n light of these principles, it is of no moment that the AUMF does not use specific language of detention. Because detention to prevent a combatant's return to the battlefield is a fundamental incident of waging war, in permitting the use of "necessary and appropriate force," Congress has clearly and unmistakeably authorized detention in the narrow circumstances considered here.'

12 Ibid, 536: '[w]hatever power the United States Constitution envisions for the Executive in its exchanges with other nation or with enemy organizations in times of conflict, it most assuredly envisions a role for all three branches when individual liberties are at stake'.

${ }^{13}$ This has not always been the case. Traditionally, because Parliamentary permission in matters of national security has been extremely broad, the constitutional union of Parliamentary Sovereignty and the rule of law in providing legislative justification or judicial review proved, for most of the $20^{\text {th }}$ century, to be nominal at best. As Lord Atkinson put it in $R v$ Halliday [1917] AC 260, 271: '[however] precious the personal liberty of the subject may be, there is something for which it may well be, to some extent, sacrificed by legal enactment, namely, national success in the war'. And again in Liversidge v Anderson [1942] AC 206, 220, the House of Lords, this time during World War II, dismissed the involvement of the judiciary in supervising the decisions made under executive discretion: 'I cannot myself believe that those responsible for the Order in Council could have contemplated for a moment the possibility of the action of the Secretary of State being subject to the discussion, criticism and control of a judge in a court of law'. See also: Council of Civil Service Unions v Minister for Civil Service [1985] AC 374 (GCHQ). 
schemes are meant to comply with ECHR Article 6 fair trial requirements and afford some judicial review of executive decision making. ${ }^{14}$ Nevertheless, the language still provides for significant executive discretion. It is worth noting that even though Parliament is technically free to create a much more unbounded system, the political and legal pressure to comply with ECHR rights has led to statutorily sanctioned judicial review. ${ }^{15}$ And the courts have employed the requirements of proportionality analysis to substantively engage with the particular interests and restrictions of rights involved in each case and expand the role of judicial review of executive decision making beyond what the statutory language implies. ${ }^{16}$

What the look at the lower court decisions of each country putting the regime into practice demonstrates is a significant difference in judicial process and judicial deference. In the United States, the emphasis on the scope of institutional powers, or domains, has resulted in a highly deferential review. In the United Kingdom, the limit on executive power does not come from abstract and generalized determinations of institutional domains but from ECHR rights, the result of which is judicial analysis of the particular context of the case and how the various interests and powers interact to either justify the measures imposed or demand their termination.

\footnotetext{
${ }^{14}$ Anti-Terrorism, Crime and Security Act 2001, s 25: 'A suspected international terrorism may appeal to the Special Immigration Appeals Commission against his certifications under section 21 [...] the Commission must cancel the certificate if-(a) it considered that there are no reasonable grounds for a belief or suspicion of the kind referred to in section 21(1)(a) or (b)'); Prevention of Terrorism Act 2005, s 3(10): 'the function of the court is to determine whether any of the following decisions of the Secretary of State was flawed'; Terrorism Prevention and Investigation Measures Act 2011, s 9: 'the function of the court is to review the decisions of the Secretary of State that the relevant conditions were met and continue to be met'.

${ }^{15}$ Even before the passage of the Human Rights Act 1998, the decisions of the Strasbourg court had begun to place pressures on Parliament to develop statutory schemes which implicated Convention rights with adequate safeguards in mind. Chahal v United Kingdom (1997) 23 EHRR 413 found the UK deportation system, and appeal process through judicial review, failed to satisfy Arts 5(4) and 13 of the European Convention on Human Rights. To comply with the decision of the European Court of Human Rights, UK Parliament passed the Special Immigration Appeals Commission Act 1997 and established the Special Immigration Appeals Commission (SIAC). SIAC's decisions, procedures and standards of review have been extremely influential.

${ }^{16}$ The proportionality review is implicated because even if the individual's liberty interests aren't directly implicated, other, qualified, Convention rights often are. For example the Art 8 right to respect for private and family life or the Art 9 right to freedom of thought, conscience and religion. See generally J Rivers, 'Proportionality and Variable Intensity of Review' (2006) 65 CLJ 174; T Hickman, 'The substance and structure of proportionality' [2008] Public Law 694; T R S Allan, 'Judicial deference and judicial review: legal doctrine and legal theory' (2011) 127 LQR 96.
} 


\section{United States: Due Process of War}

Following the attacks of 11 September 2001, and more specifically, the ground war in Afghanistan, the President, operating with congressional authority under the Authorization for the Use of Military Force $(A U M F){ }^{17}$ began capturing and detaining 'enemy combatants'. Guantanamo Bay houses mostly third-state detainees who were captured either by US forces in Afghanistan or handed over to the United States by allied powers, most notably the Northern Alliance in Afghanistan, and Pakistani officials who scooped up a great many people fleeing Afghanistan in the early days of the invasion. ${ }^{18}$ The AUMF authorizes the President

$[\mathrm{T}] \mathrm{o}$ use all necessary and appropriate force against those nations, organizations, or persons he determines planned, authorized, committed, or aided the terrorist attacks that occurred on September 11, 2001, or harboured such organizations or persons, in order to prevent any future acts of international terrorism against the United States by such nations, organizations, or persons. ${ }^{19}$

War powers, argued the Bush Administration, displace the regular institutional ordering. Congress has no authority to 'place any limits on the President's determinations as to any terrorist threat, the amount of military force to be used in response, or the method, timing, and nature of the response. ${ }^{20}$ This conclusion derived from a broader institutional claims that 'the constitutional structure requires that any ambiguities in the allocation of a power that is executive in nature, such as the power to conduct military hostilities, must be resolved in favour of the executive branch, ${ }^{21}$ or that 'the Constitution makes clear that the process used for conducting military hostilities is different from other government decision making. ${ }^{22}$ Or, in the metaphor Justice Holmes used, thrusting off the enemy is not

${ }^{17}$ Authorization for Use of Military Force 2001 (AUMF). See also USA PATRIOT Act.

${ }^{18}$ See The Report of the Constitution Project's Task Force on Detainee Treatment, <http://detaineetaskforce.org/report/> [accessed 28 September 2014].

${ }^{19}$ AUMF, 224.

${ }^{20}$ J C Yoo, Deputy Assistant Attorney General, 'The President's Constitutional Authority to Conduct Military Operations Against Terrorists and Nations Supporting Them - Memorandum Opinion for the Deputy Counsel to the President' (25 September 2001), extracted in K L Greenberg \& J L Dratel (eds), The Torture Papers: The Road to Abu Ghraib (2005) 3.

${ }^{21}$ Ibid (emphasis added).

${ }^{22}$ Ibid. 
done through the regular process of rigorous institutional power, or decision, sharing. The need for swift and unified action means one branch decides. The Courts have rejected this argument in its extreme, insisting on enforcing structural constitutional limits. As Justice O'Connor wrote in her plurality opinion in Hamdi v Rumsfeld: 'Whatever power the United States Constitution envisions for the Executive in its exchanges with other nation or with enemy organizations in times of conflict, it most assuredly envisions a role for all three branches when individual liberties are at stake. ${ }^{23}$ But the result is continued emphasis on such institutional concerns.

Rasul $v$ Bush ${ }^{24}$ and Hamdi $v$ Rumsfeld were two cases decided in the third year of the conflict in Afghanistan. The cases concerned detainees captured in Afghanistan. In Rasul the detainees were aliens; in Hamdi the detainee was a US citizen. They had been apprehended in an active conflict zone overseas and were being detained by the Commander in Chief. Because Hamdi was a US citizen the Court had to directly confront the scope of rights which would reach a person caught in the executives war powers. No one opinion commanded the majority but Justice O'Connor's plurality opinion and Justice Scalia's dissent differed fundamentally on the question of how Bill of Rights protections could operate in this conflict and how the structural considerations ought to influence the answer to the first question. Justice O'Conner, in her opinion for the Court, held the AUMF to be an act of Congress authorizing the detention of combatants in the ground war in Afghanistan. Hamdi's detention fell within executive prerogative, necessarily authorized as incident to the execution of war.

In light of these principles, it is of no moment that the AUMF does not use specific language of detention. Because detention to prevent a combatant's return to the battlefield is a fundamental incident of waging war, in permitting the use of 'necessary and appropriate force', Congress has clearly and unmistakeably authorized detention in the narrow circumstances considered here. ${ }^{25}$

But this was no straightforward matter. Hamdi was not a citizen of an enemy state, nor his association with a foreign military apparatus beyond dispute. He was entitled to have his status determined, as part of his constitutional

\footnotetext{
${ }^{23}$ Hamdi, above n 2, 536.

${ }^{24}$ Rasul v Bush, 542 US 466 (2004) (Rasul).

${ }^{25}$ Hamdi, above n 2, 519.
} 
right to due process, before finding himself wholly within executive control. ${ }^{26}$ Instead of wholly deferring to the executive, Justice O'Conner placed the Court in the position to balance the extraordinary constitutional demands on both sides of the case: 'the process due in any given instance is determined by weighing "the private interest that will be affected by the official action" against the Government's asserted interest, "including the function involved" and the burdens the Government would face in providing greater process. ${ }^{27}$

If an impassioned defence of both constitutional safeguards of individual liberty and institutional overreaching needed a voice, in this case it found a champion in Justice Scalia's dissenting opinion: ${ }^{28}$ '[ $t$ ] he very core of liberty secured by our Anglo-Saxon system of separated powers has been freedom from indefinite imprisonment at the will of the Executive. ${ }^{29}$ The Due Process Clause is how this great freedom is protected, and the Suspension Clause is how the Constitution accommodates measures made necessary by grave threats. ${ }^{30}$ Absent such an emergency and a suspension, there is no judicial fashioning allowed to fill gaps of Executive illegality. ${ }^{31}$ Justice Scalia took great issue with robbing due process of its substantive content. It is an approach premised on functionality of judicial enforcement of constitutional rights which Justice Scalia has long opposed, generally:

[Flexibility] might be a persuasive argument if most of the 'growing' that the proponents of this approach have brought upon us in the past, and are determined to bring upon us in the future, were the

\footnotetext{
${ }^{26}$ Ibid, 526: 'Under the definition of enemy combatant that we accept today as falling within the scope of Congress' authorization, Hamdi would need to be "part of or supporting forces hostile to the United States or coalition partners" and "engaged in an armed conflict against the United States" to justify his detention in the United States for the duration of the relevant conflict'.

${ }^{27}$ Ibid, 529.

${ }^{28}$ Ibid, 554: 'When the Government accuses a citizen of waging war against it, our constitutional tradition has been to prosecute him in federal court for treason or some other crime. Where the exigencies of war prevent that, the Constitution's Suspension Clause, Art I, $\$ 9, \mathrm{cl} 2$, allows Congress to relax the usual protections temporarily. Absent suspension, however, the Executive's assertion of military exigency has not been thought sufficient to permit detention without charge.'

${ }^{29}$ Ibid, 555.

${ }^{30}$ It is worth noting that while Justice Scalia takes great issue with the court's disregard of clear constitutional rules, he does not sustain it when it is an alien-combatant who seeks similar access to due process: see Hamdan v Rumsfeld, 548 US 557 (2006).

31 A Scalia, A Matter of Interpretation (1997) 41.
} 
elimination of restrictions upon democratic government. But just the opposite is true. ${ }^{32}$

Now, the strong rights protective and rights focused argument that Justice Scalia defends is premised on a bright line distinction which would permit unbounded authority of the executive on the other side of the line. That line is citizenship. If the individual is an American, he gets all the rights due him under the Constitution. If not, then no rights are implicated and the Courts have no role to play. This approach was rejected by the courts in Rasul and Boumediene.

In Rasul, writing for the majority, Justice Stevens' opinion asks, in a particularly pointed section, why the presumption against extraterritorial reach of US law should stop the writ from applying to aliens at Guantanamo if it applied to citizens in the same circumstances. ${ }^{33}$ These detainees were not citizens of a country at war with the United States, and they had not been found guilty of taking up arms against the US or coalition forces. What justified the use of the claimed war powers? ${ }^{34}$ While the court had treated citizenship as a salient factor in war powers in the past, ${ }^{35}$ especially assuming certain categorical justifications based on alienage ${ }^{36}$ the nature of the threat from international terrorism means the same underlying logic requires significant judicial investigation before it can be made to apply. The relevant question had become the person's ties to the organizations implicated by the AUMF.

${ }^{32}$ Ibid.

${ }^{33}$ Rasul, above n 24, 497.

${ }^{34}$ Ibid, 475-76, 486, citing the six 'Eisentrager factors': 'he (a) is an enemy alien; (b) has never been or resided in the United States; (c) was captured outside of our territory and there held in military custody as a prisoner of war; (d) was tried and convicted by a Military Commission sitting outside the United States; (e) for offenses against laws of war committed outside the United States; ( $\mathrm{f}$ ) and is at all times imprisoned outside the United States.'

${ }^{35}$ In Johnson v Eisentrager, 339 US 763 (1950) (Eisentrager), Jackson J took particular notice of the nature of modern warfare to determine the scope of the laws of war. How it demands complete allegiance from citizens. This allegiance, to a foreign nation at war with the United States, was the basis for leaving the case to military authorities. 'Conscription, compulsory service and measures to mobilize every human and material resource and to utilize nationals-wherever they may be-in arms, intrigue and sabotage, attest the prophetic realism of what once may have seemed a doctrinaire and artificial principle': Eisentrager, above n $35,772-73$.

${ }^{36} \mathrm{Ibid}, 775$ : "The resident enemy alien is constitutionally subject to summary arrest, internment and deportation whenever a "declared war" exists. Courts will entertain his pleas for freedom from Executive custody only to ascertain the existence of a state of war and whether he is an alien enemy and so subject to the Alien Enemy Act. Once these jurisdictional elements have been determined, court will not inquire into any other issue as to his internment.' 
However, unlike Justice Scalia's argument in Hamdi, the Court in Boumediene $v$ Bush made clear it was not going to determine the substance of the rights these detainees enjoyed or how the Bill of Rights applied to them. ${ }^{37}$ The Suspension Clause and the separation of powers concerns it raised was the show everyone had come to see. At issue was the role of the judiciary, without which liberties won and codified after centuries of fight, failure, and fortitude, would be lost: '[the] protection for the privilege of habeas corpus was one of the few safeguards of liberty specified in a Constitution that, at the outset, had no Bill of Rights. ${ }^{38}$ In Boumediene $v$ Bush, the detainees were all aliens, but none of them were nationals of a state at war with the United States. ${ }^{39}$ They had all been found by Combatant Status Review Tribunals (CSRT) to qualify as enemy combatants, but they continued to deny their membership in both al-Qaeda and the Taliban. Looking to World War II case law as well as the Court's own Suspension Clause jurisprudence, Justice Kennedy produced the following three factors to evaluate the wisdom of judicial involvement:

(1) the citizenship and status of the detainee and the adequacy of the process through which the status determination was made; (2) the nature of the sites where apprehension and the detention took place; and (3) the practical obstacles inherent in resolving the prisoner's entitlement to the writ. ${ }^{40}$

Finding the CSRT procedures wanting, their process inadequate, the Court overruled the congressional removal of judicial jurisdiction. Absent a suspension, the writ is available. The great writ protects a person from being detained illegally. Whether someone is detained pursuant to law depends on what law governs. The Suspension Clause cannot go on its own to Guantanamo without bringing some law with it. Justice Kennedy focused on the extraterritorial reach of the writ, not the extraterritorial reach of the law which either protects the detainee or makes his detention legal.

What these cases reveal is that the Supreme Court is working to apply a familiar set of legal principles to the challenges posed by the current conflict.

\footnotetext{
${ }^{37}$ Boumediene v Bush 553 US 723 (2008) (Boumediene).

38 Ibid, 731.

${ }^{39}$ Ibid, 723: 'We do not address whether the President has authority to detain these petitioners nor do we hold that the writ must issue'. See also S Vladeck, 'Boumediene's Quiet Theory: Access to Courts and the Separation of Powers' (2009) 84 Notre Dame LR.

${ }^{40}$ Boumediene, above n 37, 759-60.
} 
But more than a focus on directly how the individual rights provided by the US Constitution may apply or the reality of the impact it has on the people subject to this power, the court has instead focused on defining the scope of institutional domains. There is no simple soldier/civilian distinction around which the Court can determine an all or nothing reach of the Bill of Rights. There is no direct connection between the civilians within any state and the de facto regional authority (or powerful international terrorist organization) operating within the borders. Justice O'Connor, in her opinion in Hamdi noted just this challenge:

[W]e understand Congress' grant of authority for the use of 'necessary and appropriate force' to include the authority to detain for the duration of the relevant conflict, and our understanding is based on longstanding law-of-war principles. If the practical circumstances of a given conflict are entirely unlike those of the conflicts that informed the development of the law of war, that understanding may unravel. $^{41}$

The Fifth Amendment right to due process prior to a deprivation of life, liberty, and property is the constitutional hook for judicial scrutiny of how the executive negotiates these new realities. Due process explicitly requires the weighing of interests asserted by the government against the loss suffered by the individual detainee. But if the only question is one of proper placement of an individual within a category of either full judicial oversight or complete executive discretion, the court is not actually engaging with the due process right to liberty but instead, it is engaged in a boundary drawing exercise which ultimately diminishes the courts enforcement of individual rights.

\section{United Kingdom and Proportionality}

After the attacks of 11 September 2001, the UK Parliament enacted AntiTerrorism, Crime and Security Act 2001 (ATCSA). Section 23 of this Act gave the government power to indefinitely detain aliens, who posed a risk to national security, if deportation was not possible (due to risk of torture if sent back to their home country or some other practical hindrance). The government had issued a Derogation Order in order to sustain the suspension of ECHR Article 5 right to

${ }^{41}$ Hamdi, above n 2, 521. 
liberty and security. Nine non-nationals designated a risk to the national security of the United Kingdom were detained but could not be deported. They appealed their indefinite detention to SIAC. The commission found there was a public emergency but that section 23 of the Act was not strictly required to confront that threat especially if British nationals with similar ties and intentions were left free to roam. Lord Bingham explained the role of the judiciary: the courts would not look too closely, or challenge, the merits of the governments declaration that there was a state of emergency, ${ }^{42}$ but, because derogation was only permitted so far as it was strictly necessary, the courts would look at the measure, the statutory authorization, to determine whether the powers conferred were strictly necessary to combat the emergency. In other words, was the indefinite detention of non-nationals suspected of being involved in international terrorism strictly necessary for, or reasonably related to, neutralizing the threat? ${ }^{43}$

For a conflict on a global stage, an enemy without a state, how would removing any one suspected individual from the United Kingdom remove the threat? The zone of human rights free discretion was not the right size. The court is searching, asking questions of the political branches but for the majority of the bench the questions surrounding the existence and gravity of the emergency is not of particular judicial competence or concern.

There was a great deal of prophesying of what would come next. If the discretion to detain were extended to include British subjects, would the courts back off? Would such a broadening of scope for executive power be better, even if the scope was less discriminating? But, instead of an expansion in the use of indefinite detention, the government switched to a new tool: control orders.

Under the Prevention of Terrorism Act 2005 the Secretary of State was empowered to issue a control order pursuant to a determination that there are 'reasonable grounds for suspecting that the individual is or has been involved in terrorism-related activity. ${ }^{, 4}$ Under section 3(1)(a) of the Act, the Secretary of State can apply to the court for permission to make a non-derogating order, which the court can grant or quash after considering 'whether the Secretary of

\footnotetext{
$\overline{42}$ In A v Secretary of State for the Home Department [2004] UKHL 56, para 29, Lord Bingham, while deploying the proportionality analysis, did acknowledge the importance of recognizing the 'relative institutional competence' or the branches involved. For the question of whether there is a public emergency 'that great weight should be given to the judgment of the Home Secretary [...] because they were called on to exercise a preeminently political judgment. It involves making a factual prediction of what various people around the world might or might not do, and when (if at all) they might do it, and what the consequences might be if they did.'

${ }^{43}$ Ibid, para 30.

${ }^{44}$ Prevention of Terrorism Act 2005, s 2(1).
} 
State's decision that there are grounds to make that order is obviously flawed. ${ }^{45}$ This power could be used against citizens and aliens alike. Between 2005 and 2011, a total of 52 people were subject to control orders, 24 of whom had British citizenship. When the control orders were introduced, they were only used against aliens, those who had been subject to detention under the ATCSA. ${ }^{46}$ In 2011 the control order system was replaced by Terrorism Prevention and Investigation Measures Act (TPIM). What the following cases show is the courts grappling with the task of independently determining the weight of the interests at stake through a context specific analysis filled with executive assessment and claims of executive expertise, if not institutional superiority. But the independent emphasis on ECHR rights that they do apply has had a significant impact on overcoming the pull, or the appeal, of complete deference. Rights are the proper domain of the judiciary and they need not, cannot, abdicate their duty to enforce them.

In Home Secretary $v M B$, the House of Lords had to consider whether a control order that relied on closed material (material not available to the person challenging the control order imposed upon them) violated the fair trial requirements of ECHR Article $6{ }^{47}$ The House of Lords decision focused on the question of minimum procedural rights necessary for the guarantee of fair trial to be satisfied. However, it is the Court of Appeal decision that took on the question of how to give effect to proportionality review while still respecting the expertise and proper institutional competence of the executive. What is the proper level of deference the court should show to the Secretary of State? The Secretary of State is better placed than the court to decide the measures that are necessary to protect the public against the activities of a terrorist suspect and, for this reason, a degree of deference must be paid to the decisions taken by the Secretary of State. ${ }^{48}$ This sentiment from Lord Phillips is not unfamiliar to

\footnotetext{
${ }^{45}$ Ibid, s 3(2)(a).

${ }^{46}$ D Anderson QC, Control Orders in 2011: Final Report of the Independent Reviewer on the Prevention of Terrorism Act 2005 (2012) 30.

${ }^{47}$ Secretary of State for the Home Department v MB [2008] 1 AC 440, 472 (Lord Bingham): 'the application of the civil limb of article 6(1) does in my opinion entitle such person to such measure of procedural protection as is commensurate with the gravity of the potential consequences'. See also AT v Secretary of State for the Home Department [2012] EWCA Civ 42, where the evidence that AT remained a member of the Libyan Islamic Fighting Group $(L I F G)$ after his arrest, prosecution, and conviction, was in closed material, the process imposing the control order violated the requirements of fair trial.

${ }^{48}$ Secretary of State for the Home Department v MB [2007] QB 415, 438-9, citing Secretary of State for the Home Department v Rehman [2003] 1 AC 153.
} 
the kind of deference the courts have shown to the executive when the case is wrapped up in national security policies. And, the statutory language does not indicate a more searching review. Section 3(2) of the Prevention of Terrorism Act (PTA) empowers the courts to review the decisions of the Secretary of State. It states 'the function of the court is to consider whether the Secretary of State's decision that there are grounds to make that order is obviously flawed. ${ }^{49}$ But Lord Phillips went on. 'Notwithstanding such deference', he wrote, 'there will be scope for the court to give intense scrutiny to the necessity for each of the obligations imposed on an individual under a control order, and it must do so. ${ }^{, 50}$

The courts have gone on to interpret the intensity of judicial scrutiny under section 3(10) of the PTA, evaluating whether the individual has participated in 'terrorism related activity', so as to require the reviewing judge:

to make up [his own] mind whether there are reasonable grounds for the necessary suspicion, having considered all the evidence put before [him]. The test is an objective one: it presupposes the existence of facts or information which would satisfy an objective observer that the person concerned may have been involved in terrorism-related activity. ${ }^{51}$

It is at the next stage of analysis, reviewing whether the measures imposed are proportionate to the ongoing threat posed by the person, which requires the courts to walk the fine line between deferring to the Secretary of State on assessments of risk and dangerousness while still providing a significant level of protection for the individuals involved. That balance is not an easy one especially since the kind of conduct alleged will strongly compel a certain belief of dangerousness which intern justifies the restriction on individual civil rights, as it did in the case of Secretary of State for the Home Department $v C D .{ }^{52}$ Where the gravity of the alleged terrorism related activity influenced the interpretations of

\footnotetext{
${ }^{49}$ Prevention of Terrorism Act 2005, s 3(2).

${ }^{50}$ Secretary of State for the Home Department $v$ MB [2007] QB 415, 439.

${ }^{51} R$ (on the application of Secretary of State for the Home Department) $v$ Bullivant [2008] EWHC 337 (Admin), para 11 (Collins J). See also A Tomkins, 'National security and the role of the court: a changed landscape?' (2010) $126 L Q R$ 543, 555: 'The effect of the Court of Appeal's decision in MB, as subsequently summarized by Collins $\mathrm{J}$ in Bullivant, is deliberately to overlook that difference and to re-conceive of the courts' powers under the 2005 Act as if they are the same as were SIAC's powers under the 2001 Act'.

${ }^{52}$ Secretary of State for the Home Department v CD [2012] EWHC 3026 (Admin), para 22 (Ouseley J).
} 
the court of the relative inactivity on the part of the controlee to mean continued intent to engage in TRA rather than the opposite, the court agreed that:

[the] more realistic assessment is not that he never was engaged in such activities or that he has changed his mind about their merits; it is that the effect of the Control Order, inclusion the removal to Leicester, the temporary experience of custody in Belmarsh, and now the TPIM, have made him decide to keep a low profile, and to behave more normally for a while..$^{53}$

On the other hand, in Secretary of State for the Home Department $v$ Al Saadi Justice Wilkie revoked a control order finding that given the passage of time and the controlees statements that he wished to return to a normal life, there was not sufficient evidence to create a reasonable suspicion that he posed an ongoing threat. ${ }^{54}$ In fact, Justice Wilkie acknowledged 'that in coming to this judgment I am, to an extent, not accepting the assessment of risk of the Security Service and the Secretary of State, to which I am obliged to show some deference. ${ }^{55}$ But, the fact that the most recent activities which raised the suspicion of ongoing risk were ambiguous at best meant that 'whilst he remains disaffected from the state and mainstream UK society and may well adhere to a view of Islam with which many would feel uncomfortable, this does not of itself justify the degree of intrusion involved in a control order'. The judgment demonstrates that difference between that 'thin veneer of legality' which in practice allows the decision to be made by the Secretary of State and one subject to 'effective judicial supervision. ${ }^{56}$ If ECHR Article 6 rights are to have real effect, providing for an independent decision maker, then undue deference ought to be avoided. When the elements of the analysis cannot be so cleanly separated as to permit the assessment of risk by one branch and determination of rights by the other, the judge must turn to justifying,

\footnotetext{
${ }^{53}$ Ibid.

${ }^{54}$ Secretary of State for the Home Department v Al Saadi [2009] EWHC 3390 (QB), para 185.

${ }^{55}$ Ibid, para 186.

${ }^{56}$ Re MB [2006] EWHC 1000 (Admin), para 103. See also Secretary of State for the Home Department $v$ $A V$ [2009] EWHC 902 (Admin), para 22: 'developments, [the negotiations between the rebels and the Libyan government], pose the critical question in the case: is the decision of the Secretary of State that it is necessary, for purposes connected with protecting members of the public from a risk of terrorism, to continue the control order in force, flawed? For the reasons already explained, the only section of the public which it may be necessary to protect from a risk of terrorism associated with AV is that identified in the "manifesto": the Libyan government and its security organs.'
} 
holistically/contextually, why the outcome best accommodates all the interests at stake.

\section{Due Process: Rights or Institutional Powers?}

Contrast the level of judicial analysis involved in balancing the proper need for deference against the need for judicial definition and protection of convention rights under the control order jurisprudence against the US courts' analysis under Fifth Amendment due process test. Justice O'Connor, in Hamdi, named the interests at stake for those subject to executive detention as 'the most elemental of liberty interests-the interest in being free from physical detention by one's own government. ${ }^{57}$ How the right is defined matters, especially when it comes to due process. Because the Due Process Clause is not a prohibition on depriving someone of life, liberty, or property, but a requirement that it be done in a way that minimizes an erroneous deprivation, the weight of the interests on each side of the balancing matters a great deal. ${ }^{58}$ Unsurprisingly, the right to be free from wrongful imprisonment is more fundamental than the right of individuals captured in the field of battle to be properly classified as enemy combatants. These rights will have different pedigrees in case law and different weights for determining judicial deference. The same is true of the governmental interest at stake. Again, Justice O'Connor in Hamdi defined it as 'the weighty and sensitive governmental interests in ensuring that those who have in fact fought with the enemy during a war do not return to battle against the United States. ${ }^{59}$ This interest is significantly different than the broader, and presumably much weightier, one of 'winning the war against global terrorism'.

\footnotetext{
${ }^{57}$ Hamdi, above n 2, 529. The opinion cites the following cases supporting the Court's modifications to the traditional due process guaranteed to individuals facing deprivation of liberty: Mathews $v$ Eldridge, 424 US 319 (1976) (pre-deprivation hearing for the loss of social security benefits); Heller $v$ Doe, 509 US 312 (1993) (involuntary commitment for mentally ill or mentally handicapped); Zinermon v Burch, 494 US 113 (1990) (voluntary commitment to mental health facility while intoxicated); United States v Salerno, 481 US 739 (1987) (pre-trial detention of defendants determined to pose a danger); Schall v Martin, 467 US 253 (1984) (pre-trial detention of juveniles); and Addington v Texas, 441 US 418 (1979) (Addington) (involuntary commitment of a patient raised from 'preponderance of the evidence' standard to 'clear and convincing' evidence)

${ }^{58}$ See e.g. Addington, above n 57, 427: 'The individual should not be asked to share equally with society the risk of error when the possible injury to the individual is significantly greater than any possible harm to the state. We conclude that the individual's interest in the outcome of a civil commitment proceeding is of such weight and gravity that due process requires the state to justify confinement by proof more substantial than a mere preponderance of the evidence.'

${ }^{59}$ Hamdi, above n 2, 531.
} 
After the Supreme Court's decisions in Hamdi and Boumediene, the D.C. district and circuit courts were left to work out the details of judicial review of CSRT designations of enemy combatant status and the requirements of due process balancing. Quickly, the court began identifying the category of people who were subject to detention, this became the whole of the judicial analysis, it served as a substitute for balancing the interests in each case. If the individual could be reasonably considered a member of 'enemy forces', then the balance of interests was satisfied through an appeal to a constitutionally pre-determined balancing. The underlying assumption is that the constitution has already performed the balancing of interests when it vested the Commander in Chief powers in the Executive. The courts are therefore not empowered to look into the specific interests of the state in each case and the harm which the individuals suffer because that would mean conducting this balancing anew. But if the courts cannot engage in any real analysis of the different interests and rights at stake because the constitution has already done so, it becomes difficult to defend or assert judicial review. This perspective is starkly stated by Judge Silberman of the DC Circuit when he described the Supreme Court's handling of Guantanamo cases as a 'defiant-if only theoretical-assertion of judicial supremacy'. ${ }^{60}$

As the courts worked through the substance of the applicable law, and therefore the limits on executive autonomy, the core of the analysis was driven by arguments of implied limits on institutional powers. At the outset, the main body of law that promised some substantive elements for judicial enforcement was the law of armed conflict. In Hamlily $v$ Obama, the DC District Court held ' $t$ the President also has the authority to detain persons who are or were part of Taliban or al Qaeda forces or associated forces that are engaged in hostilities against the United States.' ${ }^{\prime}$ The standard is not ongoing dangerousness. Why? Under the laws of war, or more specifically the Geneva Conventions, the requirement for detention is not individualized dangerousness, but status. Soldiers, members of enemy armed forces, can be detained until the 'cessation of active hostilities.' ${ }^{62}$ Since authorization from Congress is a declaration of war, the power it authorized is the accepted war powers of the state in domestic

\footnotetext{
${ }^{60}$ Esmail v Obama, 639 F 3d 1075, 1078 (DC Cir, 2011) (Silberman J, concurring).

${ }^{61}$ Hamlily v Obama, 616 F Supp 2d 63, 78 (DDC, 2009) (Hamlily); adopted by the DC circuit in: Al-Bihani v Obama, 590 F 3d 866, 872 (DC Cir 2010) (Al-Bihani); Barhoumi v Obama, 609 F 3d 416, 432 (DC Cir, 2010).

${ }^{62}$ Al-Bihani, above n 61, 874. Awad v Obama, 608 F 3d 1 (DC Cir, 2010) (Awad): 'Al-Bihani makes plain that the United States' authority to detain an enemy combatant is not dependent on whether an individual would pose a threat to the United States or its allies if released but rather upon the continuation of threat of hostilities'. See also Statement by Harold Hongju Koh, Sterling Profes-
} 
and international law. The government and petitioner in Hamlily made claims based on analogizing the current conflict with the kinds of conflicts which are the subject of international laws of war, i.e. international armed conflict and non-international armed conflict. However, in navigating these claims the court acknowledged that 'the government's position cannot be said to reflect customary international law because, candidly, none exists on this issue. ${ }^{63}$

As the cases reached the DC Circuit, the lack of clear authority, clear custom, in international armed conflict took on a particular significance. Not long thereafter, the DC Circuit abandoned the use of international law, generally, as a limit on the President's commander in chief powers:

There is no indication in the AUMF [...] that Congress intended the international laws of war to act as extra-textual limiting principles for the President's war powers under the AUMF. The international laws of war as a whole have not been implemented domestically by Congress and are therefore not a source of authority for US courts. ${ }^{64}$

There is the concern that too rigorous a review based on judicial analysis, whether driven by judicially created standards or through an appeal to international law, will mean overstepping into the law making function and thereby hamper the needed flexibility of the military authorities. The DC Circuit opinion in Al-Bihani went on to point out, that part of the legislative power to make law for the United State meant that 'Congress had the power to authorize the President in the AUMF and other later statutes to exceed [the] bounds [of customary international law of armed conflict]. ${ }^{65}$ This statement of possible legislative action has the predominant effect of limiting judicial review. The court does not go on to ask whether the standards of customary international law should inform the due process analysis but understands from their 'fluidity' a wide berth for executive discretion. This is the central preoccupation of the separation of powers

sor of International Law, The Yale Law School, before the Senate Foreign Relations Committee (21 May 2014) <http://www.foreign.senate.gov/imo/media/doc/Koh_Testimony.pdf> [accessed 6 November 2014].

${ }^{63}$ Hamlily, above n 61, 74 .

${ }^{64}$ Al-Bihani, above n 61, 871.

${ }^{65}$ Ibid: "[t]herefore, while the international laws of war are helpful to courts when identifying the general set of war powers to which the AUMF speaks [...], their lack of controlling legal force and firm definition render their use both inapposite and inadvisable when courts seek to determine the limits of the President's war powers'. 
rhetoric, safeguarding the domain of Presidential war powers. ${ }^{66}$ As Judge Brown put it, "[these] cases present hard questions and hard choices, ones best faced directly. Judicial review, however, is just that: re-view, an indirect and necessarily backward looking process. ${ }^{67}$

The DC Circuit has gone on to perform their review through engaging in case by case functional determination of membership. If an individual can be said to be a 'part of' al-Qaeda, the Taliban, or associated forces, then they are detainable until the end of the conflict pursuant to the President's war powers. ${ }^{68}$ Whether someone is part of one of these groups is not ascertained through formal proof of membership or evidence of having been part of the hierarchy of the organization. The standard is flexible. ${ }^{69}$ Without a body of law to define the preventative detention powers of the President, either statutory or customary, the judiciary has found deference a more compelling institutional response.

In addition to the substantive berth, the procedural rules adopted by the DC Circuit have substantially relaxed the evidentiary and procedural review. The courts have not required clear and convincing evidence but held preponderance of the evidence standard more than satisfied constitutional due process. ${ }^{70}$ In fact, preponderance of the evidence may be more than is required, which is reflected in the courts 'some evidence' approach in practice. ${ }^{71}$ And the evidence relied upon need not be evaluated individually so as to isolate the basis of the detention to independently reliable evidence, the courts have turned to the 'conditional

${ }^{66}$ Ibid, 878: 'placing a lower burden on the government defending a wartime detention-where national security interests are at their zenith and the rights of the alien petitioner at their nadir-is also permissible'.

${ }^{67}$ Ibid, 882 (Brown J, concurring). See also S Vladeck, 'The DC Circuit After Boumediene' (2011) 41 Seton Hall LR 1451.

${ }^{68} \mathrm{Al}$-Bihani, above $\mathrm{n}$ 61, 873: 'The determination of when hostilities have ceased is a political decision, and we defer to the Executive's opinion on the matter, at least in the absence of an authoritative congressional declaration purporting to terminate the war'.

${ }^{69}$ Awad, above n 62; Bensayah v Obama, 610 F $3 \mathrm{~d} 718$ (DC Cir 2010) (the case of an Algerian citizen arrested in Bosnia for suspicion of planning an attack against the US embassy, when the Bosnian police failed to find enough evidence, the Court ordered his release, at which time he was handed over to US forces); Salahi v Obama, 625 F 3d 745 (DC Cir 2010) (Salahi).

${ }^{70}$ Al-Bihani, above n 61; Al Odah v United States, 611 F $3 \mathrm{~d} 8$ (DC Cir 2010). See also Addington, above $\mathrm{n}$ 57, 425: "[i] $\mathrm{n}$ cases involving individual rights, whether criminal or civil, "[ $\mathrm{t}] \mathrm{he}$ standard of proof [at a minimum] reflects the value society places on individual liberty"'.

${ }^{71}$ Al-Adahi v Obama, $613 \mathrm{~F} 3 \mathrm{~d}$ 1102, 1105 (DC Cir 2010) (Al-Adahi): 'we are aware of no precedents in which eighteenth century English courts adopted a preponderance standard. Even in later statutory habeas cases in this country, that standard was not the norm. For years, in habeas proceedings contesting orders of deportation, the government had to produce only "some evidence to support the order."; Almerfedi v Obama, 654 F 3d 1 (DC Cir, 2011). 
probability analysis' instead. ${ }^{72}$ As the court in Al-Adahi v Obama explained, the District Court had erred by considering the weight of each piece of evidence instead of recognizing a key difference in the reasoning involved in these cases: ' $t$ ] he key consideration is that although some events are independent (coin flips, for example), other events are dependent: "the occurrence of one of them makes the occurrence of the other more or less likely". ${ }^{73}$

The Supreme Court has not taken up the questions of what law or what standards apply in reviewing CSRT findings since Boumediene. In a recent memorandum accompanying a denial of certiorari in the case of Hussain v Obama, Justice Breyer stressed that mere membership in the Taliban or al-Qaeda may not be enough to authorize executive powers of military detention. Quoting the language from Hamdi, Justice Breyer points out the statutory limits on executive power to detain individuals pursuant to the AUMF, that the individual be 'part of or supporting forces hostile to the United States or coalition partners in Afghanistan and who engaged in an armed conflict against the United States there. ${ }^{74}$ Such a purposive reading would certainly limit who can be detained under this authorization. Whether the Supreme Court would narrow the domain of executive discretion or re-focus on re-asserting the importance of the rights of the individuals subject to this power would raise different issues. The former would mean judicial assertion of power to define the proper scope of institutional powers in an armed conflict, a less deferential version of the current case law. The latter would entail a reassertion of both higher procedural requirements and tighter fit between the interests of the state and the necessity of detaining this particular individual.

\section{Conclusion}

The scenario provided by Justice Holmes to explain zealous state action in response to a threat is, like most explanatory metaphors, imperfect. For an

72 Al-Adahi, above n 71, 1105; Salahi, above n 67.

${ }^{73} \mathrm{Al}$-Adahi, above $\mathrm{n} 71,1105$ : ' $[\mathrm{t}$ ] hose who do not take into account conditional probability are prone to making mistakes in judging evidence. They may think that if a particular fact does not itself prove the ultimate proposition (e.g., whether the detainee was part of al-Qaida), the fact may be tossed aside and the next fact may be evaluated as if the first did not exist.'

${ }^{74}$ Hussain v Obama, 572 US, 2 (2014) (cert denied) (Breyer J) (emphasis added). See also Uthman $v$ Obama, 637 F 3d 400, 403 (DC Cir 2011): 'demonstrating that someone is part of al Qaeda's command structure is sufficient to show that person is part of al Qaeda. But it is not necessary.; Awad, above n 62, 11: 'Nowhere in the AUMF is there a mention of command structure'. 
individual it is a justification based on an immediately known reality and sufficiently precisely presented choice. This raft will sink if this stranger is not thrust off. But for a state, those elements must be provided for through some legal process meant to approximate the choice and present reliability and impartiality of the decision, that it is in fact the case that the raft will sink and that it is necessary to push this person off. The justification is contingent on a close fit between the circumstances and the necessity of the action. What the analysis of the quality of judicial review in the control order and Guantanamo cases has sought to show is how much the courts are involved in investigating that fit and thereby moving closer to an impartial justification. 